\title{
MODEL MATEMATIKA KENDALI OPTIMAL INTENSITAS CAHAYA DAN NUTRISI PADA PERTUMBUHAN MIKROALGA DENGAN MENGGUNAKAN METODE PONTRYAGIN
}

\author{
Azim ${ }^{1}$, R. Ratianingsih², dan N. Nacong ${ }^{3}$ \\ 1,2,3Program Studi Matematika Jurusan Matematika FMIPA Universitas Tadulako \\ Jalan Soekarno-Hatta Km. 09 Tondo, Palu 94118, Indonesia. \\ 1azimzack95@gmail.com,2ratianingsih@yahoo.com, ${ }^{3}$ nasrianacong@yahoo.com
}

\begin{abstract}
Microalgae are the most primitive plant-sized cellular organisms commonly known as phytoplankton. The habitat of its life is in waters or humid places. This organism is a primary producer of water that has any capability to photosynthesis like any other high-level plants. This study examines mathematically the optimal control of light intensity and liquid waste nutrition in microalgae growth. Growth liter is done by setting the intensity of light in the process of glucose formation and nutrition tofu liquid waste, tapioca, industry, and households as the additional nutrients of microalgae. The Pontryagin maximun principles is used to determine the optimal control solution. The solution is solved from the state and co-state equation that stationery evaluated using the indexed performance maks $J\left[u_{1}+u_{2}\right]=\int_{t 0}^{t f} G(t)-S(t)-\frac{1}{2} u_{1}(t)^{2}-\frac{1}{2} u_{2}(t)^{2} d t$ with the stationer condition that gives the optimal control $u_{1}^{*}=\gamma_{2} \alpha_{2} Q B$ and $u_{2}^{*}=-\gamma_{5} \rho_{1} S$. The results shows that before the optimal control of light intensity and nutrition of liquid waste is applied, the concentration of microalgae biomass becomes $5.915 \mathrm{~g} /$ liter on the 20th day stayed at the 105th day. The lipid quota with an initial value of $0.6 \mathrm{~g} /$ liter will decrease to $0.2 \mathrm{~g} /$ liter at $4^{\text {th }}$ day which is the equilibrium point. Optimal control of the regulation of light intensity of 2-9 klux and liquid waste nutrition provided a significant increase in the amount of microalgae biomass and lipid quota, with the regulation of light intensity of 29 klux and tofu liquid waste nutrition which gave the largest increase in the amount of microalgae biomass and lipid quota.
\end{abstract}

Keywords : Light Intensity, Lipid Quota, Liquid Waste Nutrition, Microalgae Biomass, Optimal Control

\section{ABSTRAK}

Mikroalga adalah organisme tumbuhan paling primitif berukuran seluler yang umumnya dikenal dengan sebutan fitoplankton. Habitat hidupnya adalah di perairan atau tempat-tempat lembab. Organisme ini merupakan produsen primer perairan yang mampu berfotosintesis layaknya tumbuhan tingkat tinggi lainnya. Penelitian ini mengkaji secara matematis kendali optimal intensitas cahaya dan nutrisi limbah cair pada pertumbuhan mikroalga. Pengendalian dilakukan dengan melakukan pengaturan intensitas cahaya pada proses pembentukan glukosa dan pemberian nutrisi limbah cair tahu, tapioka, industri, dan rumah tangga sebagai nutrisi tambahan mikroalga. Kendali optimal ditentukan dengan metoda maksimum Pontryagin. Dalam penelitian ini diperoleh Indeks Performance maks $J\left[u_{1}+u_{2}\right]=\int_{t 0}^{t f} G(t)-S(t)-\frac{1}{2} u_{1}(t)^{2}-\frac{1}{2} u_{2}(t)^{2} d t \quad$ dengan kondisi stasioner yang memberikan kendali optimal $u_{1}^{*}=\gamma_{2} \alpha_{2} Q B$ dan $u_{2}^{*}=-\gamma_{5} \rho_{1} S$. Hasil penelitian menunjukan bahwa sebelum 
dilakukan pengaturan intensitas cahaya dan pemberian nutrisi limbah cair, konsentrasi biomassa mikroalga meningkat menjadi 5,915 g/liter pada hari ke- 20. Untuk selanjutnya bernilai tetap pada hari ke- 105. Kuota lipid dengan nilai awal 0,6 akan menurun menjadi $0.2 \mathrm{~g} /$ liter pada hari ke- 4 yang merupakan titik setimbangnya. Kendali optimal pengaturan intensitas cahaya sebesar 2-9 klux dan pemberian nutrisi limbah cair memberikan peningkatan yang signifikan pada jumlah biomassa mikroalga dan kuota lipid, dengan pengaturan intensitas cahaya sebesar 2-9 klux dan pemberian nutrisi limbah cair tahu yang memberikan peningkatan terbesar jumlah biomassa mikroalga dan kuota lipid.

Kata Kunci : Intensitas Cahaya, Nutrisi Limbah Cair, Kuota Lipid, Biomassa Mikroalga, Kendali Optimal

\section{PENDAHULUAN}

\subsection{Latar Belakang}

Setiap tahunnya, Jumlah penduduk Indonesia semakin bertambah. Pada tahun 2010, Jumlah penduduk indonesia lebih dari 237 juta jiwa (Badan Pusat Statistik, 2012), dengan jumlah penduduk yang terus meningkat dari tahun ke tahun. Sehingga memunculkan berbagai masalah, di antaranya ketersediaan energi. Selama ini, pemenuhan kebutuhan energi di Indonesia sebagian besar dari energi yang tidak terbarukan (energi fosil) seperti minyak bumi, gas alam, dan batu bara. Tentunya, hal ini merupakan permasalahan yang sangat besar mengingat cadangan energi yang tidak terbarukan semakin lama semakin menipis. Sehingga di butuhkan suatu cadangan minyak yang terbarukan yang dapat mengurangi ketergantungan terhadap energi fosil, dan salah satu sumber energi baru dan terbarukan yang dapat mengurangi ketergantungan terhadap energi fosil yaitu Mikroalga.

Mikroalga adalah sejenis makhluk hidup unisel berukuran antara 1 mikrometer sampai ratusan mikrometer yang memiliki klorofil, hidup di air tawar atau laut, membutuhkan karbon dioksida, beberapa nutrien dan cahaya untuk berfotosintesis. Mikroalga memiliki kinerja yang hampir sama dengan tumbuhan bersel banyak, akan tetapi tidak memiliki akar, daun, dan batang untuk berfotosintesis. Menurut beberapa peneliti, mikroalga diibaratkan sebagai pabrik kecil dalam ukuran sel mikro yang mengubah karbon dioksida menjadi material potensial seperti biofuel, pangan, dan biomaterial melalui energi matahari (Chisti, 2007).

Pada penelitian sebelumnya Ratianingsih dkk. (2017) telah membahas kontrol optimal pada model dinamik pertumbuhan biomassa mikroalga dengan keterbatasan nutrisi untuk opend pond. Pada penelitian ini akan dilakukan pengontrolan model dinamik tersebut dengan melakukan pengaturan intensitas cahaya dan nutrisi limbah cair, sehingga didapatkan biomassa mikroalga yang optimal dengan menggunakan metode maksimum Pontryagin. Jenis limbah cair akan disimulasikan untuk beberapa jenis yaitu tahu, tapioka, industri, dan rumah tangga. Simulasi dibuat dengan menggunakan perangkat lunak Matlab. 


\subsection{Rumusan Masalah}

Adapun rumusan masalah dari penelitian ini adalah sebagai berikut.

1. Bagaimana model kendali optimal intensitas cahaya dan nutrisi limbah cair pada mikroalga.

2. Bagaimana analisa kestabilan model kendali optimal intensitas cahaya dan nutrisi limbah cair pada mikroalga.

3. Bagaimana intensitas cahaya dan nutrisi limbah cair yang optimal sehingga di dapatkan biomassa mikroalga yang optimal menggunakan metode maksimum Pontryagin.

\subsection{Tujuan Penelitian}

Adapun tujuan dari penelitian ini adalah sebagai berikut.

1. Mendapatkan model matematika kendali optimal intensitas cahaya dan nutrisi pada mikroalga.

2. Mendapatkan analisa kestabilan titik kritis model kendali optimal intensitas cahaya dan nutrisi limbah cair pada mikroalga.

3. Mendapatkan intensitas cahaya dan nutrisi limbah cair yang optimal sehingga di dapatkan biomassa dan lipid mikroalga yang optimal menggunakan metode maksimum pontryagin.

\section{METODE PENELITIAN}

Penelitian dilakukan sesuai prosedur dibawah ini :

1. Memulai penelitian

2. Mengkaji literatur untuk membangun model matematika kendali optimal intensitas cahaya dan nutrisi limbah cair pada mikroalga.

3. Membangun model matematika kendali optimal intensitas cahaya dan nutrisi limbah cair pada mikroalga.

4. Identifikasi eksistensi titik kritis model matematika kendali optimal intensitas cahaya dan nutrisi limbah cair pada mikroalga.

5. Menganalisa kestabilan model matematika kendali optimal intensitas cahaya dan nutrisi limbah cair pada mikroalga.

6. Simulasi model matematika kendali optimal intensitas cahaya dan nutrisi limbah cair pada mikroalga.

7. Menyimpulkan hasil penelitian. 


\section{HASIL DAN PEMBAHASAN}

\subsection{Kontruksi Model Matematika}

Dalam budidaya mikroalga, untuk memperoleh biomassa mikroalga dan lipid tinggi dilakukan pengaturan pada intensitas cahaya dan pengaturan penambahan nutrisi limbah cair. Pengoptimalan tersebut digambarkan dalam diagram kendali optimal pengaturan intensitas cahaya $\left(u_{1}\right)$ dan nutrisi limbah cair $\left(u_{2}\right)$ yang yang di tampilkan pada Gambar 1 .

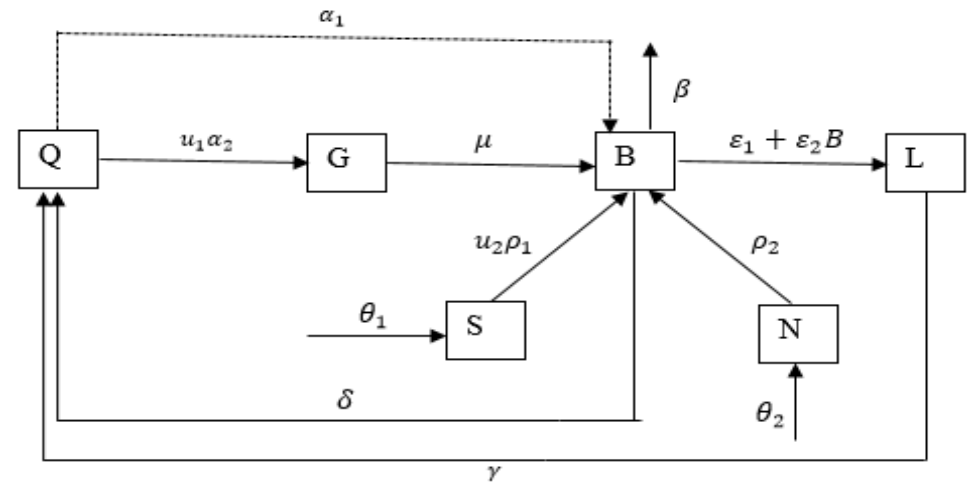

Gambar 1 : Kompartemen Produksi Biomassa Mikroalga

Dalam pembentukan biomassa mikroalga memerlukan cahaya, $\mathrm{CO}_{2}$ dan Nutrisi. $\mathrm{CO}_{2}$ diserap mikroalga melalui proses respirasi dengan laju sebesar $\alpha_{1}$, disisi lain $\mathrm{CO}_{2}$ yang diperlukan mikroalga untuk menghasilkan glukosa dengan bantuan cahaya melalui proses fotosintesis dengan laju sebesar $\alpha_{2}$. Intensitas cahaya berperan penting dalam proses fotosintesis sehingga diperlukan pengontrolan intensitas cahaya $\left(u_{1}\right)$ untuk mendapatkan pencahayaan yang optimal dengan melakukan pengaturan intensitas cahaya agar diperoleh biomassa mikroalga yang optimal. Glukosa yang dihasilkan dari proses fotosintesis akan tersimpan dalam bentuk asam lemak sehingga menghasilkan biomassa $(B)$ dengan laju pembentukan biomassa sebesar $\mu$. Biomassa memiliki kandungan lipid. Asam lemak pada biomassa mikroalga akan disintesis dengan laju sebesar $\beta$, untuk menghasilkan kuota lipid $(L)$. Asam lemak dan gliserol disintesis dengan laju sebesar $\left(\varepsilon_{1}+\varepsilon_{2} B\right)$ yang kemudian asam lemak tersebut dimobilisasi dengan laju sebesar $\gamma$ untuk menghasilkan kembali kuota karbon dioksida $(Q)$.

Secara umum, pada saat kondisi gelap, mikroalga mempertahankan hidupnya melalui respirasi sel yang membutuhkan $\mathrm{O}_{2}$ dan mengeluarkan $\mathrm{CO}_{2}$ dengan laju sebesar $\delta$. Laju pertumbuhan biomassa mikroalga tergantung pada laju penyerapan nutrisi dari limbah cair $(S)$ dan nitrogen dari pupuk urea $(N)$ oleh mikroalga berturut-turut sebesar $\rho_{1}$ dan $\rho_{2}$. Laju penyerapan nutrisi sebesar $\theta_{1}$ oleh mikroalga dipengaruhi oleh substrat nutrisi limbah cair dan nitrogen pupuk urea sebesar $\theta_{2}$ yang masuk dalam ekositem perairan. Nutrisi limbah cair 
(S) diantaranya adalah limbah cair tahu, limbah cair tapioka, limbah industri karet dan limbah rumah tangga. Tingkat penggunaan limbah cair akan dikontrol dengan mengatur tingkat konsentrasi nutrisinya $\left(u_{2}\right)$ untuk mendapatkan biomassa yang optimal dari keempat nutrisi limbah cair tersebut.

Model kendali optimal intensitas cahaya dan nutrisi pada mikroalga dinyatakan sebagai berikut.

$\frac{d Q}{d t}=\delta B+\gamma L-\alpha_{1} Q B$

$\frac{d G}{d t}=u_{1} \alpha_{2} Q B-\mu G$

$\frac{d B}{d t}=\mu G+\rho_{1} S+\rho_{2} N-\beta B$

$\frac{d L}{d t}=\varepsilon_{1}+\varepsilon_{2} B-\gamma L$

$\frac{d S}{d t}=\theta_{1}-u_{2} \rho_{1} S$

$\frac{d N}{d t}=\theta_{2}-\rho_{2} N$

\subsection{Analisa Kestabilan}

Titik kritis model yang dibangun diperoleh dengan meninjau SPD pada keadaan stagnan , sehingga diperoleh titik kritis tak nol sebagai berikut:

$Q=\frac{u_{2} \varepsilon_{1} \beta+\delta \theta_{1}+\delta u_{2} \theta_{2}+\varepsilon_{2} \theta_{1}+\varepsilon_{2} u_{2} \theta_{2}}{\alpha_{1}\left(\alpha_{1}\left(\theta_{1}+u_{2} \theta_{2}\right)+u_{1} u_{2} \alpha_{2} \varepsilon_{1}\right)}$

$G=-\frac{u_{1} \alpha_{2}\left(\varepsilon_{1} \beta u_{2}+\delta \theta_{1}+\delta u_{2} \theta_{2}+\varepsilon_{2} \theta_{1}+\varepsilon_{2} u_{2} \theta_{2}\right)}{\mu u_{2}\left(-\beta \alpha_{1}+u_{1} \alpha_{2}\left(\delta+\varepsilon_{2}\right)\right)}$

$B=-\frac{\alpha_{1}\left(\theta_{1}+u_{2} \theta_{2}\right)+u_{1} u_{2} \alpha_{2} \varepsilon_{1}}{u_{2}\left(-\beta \alpha_{1}+u_{1} \alpha_{2}\left(\delta+\varepsilon_{2}\right)\right)}$

$L=\frac{\varepsilon_{1} u_{2}\left(-u_{1} \alpha_{2} \delta+\beta \alpha_{1}\right)+\varepsilon_{2} \alpha_{1}\left(\theta_{1}+u_{2} \theta_{2}\right)}{\gamma u_{2}\left(\beta \alpha_{1}-u_{1} \alpha_{2}\left(\delta+\varepsilon_{2}\right)\right)}$

$S=\frac{\theta_{1}}{u_{2} \rho_{1}}$

$N=\frac{\theta_{2}}{\rho_{2}}$

Dengan syarat eksistensinya yaitu $\min \left\{\frac{\alpha_{1}}{\alpha_{2}}>\frac{u_{1}\left(\delta+\varepsilon_{2}\right)}{\beta}\right.$ dan $\left.\frac{\alpha_{1}}{\alpha_{2}}>\frac{u_{1} \delta}{\beta}\right\}$. Kemudian di lakukan analisa kestabilan dan diperoleh nilai eigen sebagai berikut :

$\lambda_{1}=-\gamma$

$\lambda_{2}=-\mu$

$\lambda_{3}=-u_{2} \rho_{1}$

$\lambda_{4}=-\alpha_{1} B$

$\lambda_{5}=-u_{2} \rho_{1}$

Sistem tersebut stabil karena semua nilai eigen bernilai negatif. Nilai dari $\lambda_{1}, \lambda_{2}, \lambda_{3}, \lambda_{4}$ dan $\lambda_{5}$ bernilai negatif. 


\subsection{Penyelesaian Kendali}

Untuk menentukan nilai parameter $u_{1}$ dan $u_{2}$ optimal yang memaksimumkan biomassa mikroalga dan lipid sehingga diperoleh biodiesel yang lebih banyak dikenal sebagai masalah kendali optimal. Dalam penyelesaian kendali optimal harus dibangun suatu performance index yang memaksimalkan glukosa dengan pengaturan intensitas cahaya dan kontrol nutrisi limbah cair dengan penambahan nutrisi limbah cair tahu, limbah cair tapioka, limbah cair rumah tangga, dan limbah cair industri. Hal ini disebabkan glukosa merupakan bahan bagi pembentukan biomassa yang dihasilkan dari proses fotosintesis. Performance index yang didisain dengan meminimumkan nutrisi limbah cair. Performance index yang digunakan adalah sebagai berikut :

$J\left[u_{1}+u_{2}\right]=\int_{t 0}^{t f} G(t)-S(t)-\frac{1}{2} u_{1}(t)^{2}-\frac{1}{2} u_{2}(t)^{2} d t$

Untuk memaksimumkannya, metode Maksimum Pontryagin menyatakan penentuan fungsi Hamiltonian sebagai berikut :

$$
\begin{aligned}
H= & f\left(x, u_{1}, u_{2}, t\right)+\lambda g\left(x, u_{1}, u_{2}, t\right) \\
H=[ & {\left[G-S-\frac{1}{2} u_{1}^{2}-\frac{1}{2} u_{2}^{2}\right]+\lambda_{1}\left[\delta B+\gamma L-\alpha_{1} Q B\right] } \\
& +\lambda_{2}\left[u_{1} \alpha_{2} Q B-\mu G\right]+\lambda_{3}\left[\mu G+\rho_{1} S+\rho_{2} N-\beta B\right] \\
& +\lambda_{4}\left[\varepsilon_{1}+\varepsilon_{2} B-\gamma L\right]+\lambda_{5}\left[\theta_{1}-u_{2} \rho_{1} S\right]+\lambda_{6}\left[\theta_{2}-\rho_{2} N\right]
\end{aligned}
$$

Berdasarkan Prinsip Maksimum Pontryagin, diperoleh solusi dari fungsi Hamilton berupa pengaturan intensitas cahaya dan pemberian nutrisi limbah cair yang optimal jika berlaku persamaan state, costate dan kondisi stasioner.

Penyelesaian kendali optimal dengan parameter $u_{1}$ dan $u_{1}$ diperoleh melalui persamaan state, co-state dan kondisi stasioner sebagai berikut :

a. Persamaan State

$$
\begin{aligned}
& \frac{\partial H}{\partial \lambda_{1}}=\delta B+\gamma L-\alpha_{1} Q B \\
& \frac{\partial H}{\partial \lambda_{2}}=u_{1} \alpha_{2} Q B-\mu G \\
& \frac{\partial H}{\partial \lambda_{3}}=\mu G+\rho_{1} S+\rho_{2} N-\beta B \\
& \frac{\partial H}{\partial \lambda_{4}}=\varepsilon_{1}+\varepsilon_{2} B-\gamma L \\
& \frac{\partial H}{\partial \lambda_{4}}=\theta_{1}-u_{2} \rho_{1} S \\
& \frac{\partial H}{\partial \lambda_{4}}=\theta_{2}-\rho_{2} N
\end{aligned}
$$

b. Persamaan Co-State

$$
\begin{aligned}
& \frac{\partial H}{\partial Q}=\lambda_{1} \alpha_{1} B-\lambda_{2} u_{1} \alpha_{1} B \\
& \frac{\partial H}{\partial G}=-1+\lambda_{2} \omega-\lambda_{3} \omega
\end{aligned}
$$




$$
\begin{aligned}
& \frac{\partial H}{\partial B}=\lambda_{1} \alpha_{1} Q-\lambda_{1} \delta-\lambda_{2} u_{1} \alpha_{2} Q+\lambda_{3} \beta-\lambda_{4} \varepsilon_{2} \\
& \frac{\partial H}{\partial L}=\lambda_{4} \gamma-\lambda_{1} \gamma \\
& \frac{\partial H}{\partial S}=1+\lambda_{5} u_{2} \rho_{1}-\lambda_{3} \rho_{1} \\
& \frac{\partial H}{\partial N}=\lambda_{6} \rho_{2}-\lambda_{3} \rho_{2}
\end{aligned}
$$

c. Kondisi Stasioner

$$
\begin{aligned}
& \frac{\partial H}{\partial u_{1}}=0 \\
& -u_{1}+\gamma_{2} \alpha_{2} Q B=0 \\
& u_{1}=\gamma_{2} \alpha_{2} Q B \text { dan } \\
& \frac{\partial H}{\partial u_{2}}=0 \\
& -u_{2}-\gamma_{5} \rho_{1} S=0 \\
& u_{2}=-\gamma_{5} \rho_{1} S
\end{aligned}
$$

\subsection{Simulasi}

Simulasi dilakukan untuk mendapatkan kurva kuota karbon dioksida $(Q)$, glukosa $(G)$, biomassa mikroalga (B), kuota lipid (L), nutrisi limbah cair (S), nutrisi nitrogen pupuk urea (N) tanpa kendali dan dengan kendali terhadap waktu yang menggambarkan sistem. Kondisi awal $Q(0)=0.5, G(0)=5, B(0)=0.06, L(0)=0.6, S(0)=0.2, N(0)=0.5$ diangkat dari beberapa referensi.

Nilai-nilai parameter yang digunakan dalam menggambarkan kurva pertumbuhan tersebut dinyatakan dalam Tabel 1.

Tabel 1 : Nilai Parameter

\begin{tabular}{|c|l|c|c|}
\hline Parameter & Deskripsi & Nilai & $\begin{array}{c}\text { Sumber } \\
\text { (Referensi) }\end{array}$ \\
\hline$\alpha_{1}$ & $\begin{array}{l}\text { Laju penyerapan karbon dioksida pada siang } \\
\text { hari }\end{array}$ & 0.5 & Fitriani, 2017 \\
\hline$\alpha_{2}$ & Laju proses fotosintesis & 0.05 & Hajar, 2014 \\
\hline$\mu$ & Laju produksi glukosa & 0.1 & Fitriani, 2017 \\
\hline$\rho_{1}$ & Laju penyerapan substrat Nutrisi limbah cair $S$ & 0.2 & Fitriani, 2017 \\
\hline$\rho_{2}$ & Laju penyerapan Nitrogen $N$ & 0.3 & Fitriani, 2017 \\
\hline$\theta_{1}$ & $\begin{array}{l}\text { Substrat Nutrisi limbah cair S yang masuk } \\
\text { kedalam ekosistem perairan }\end{array}$ & 1.7 & Nacong, 2014 \\
\hline$\theta_{2}$ & $\begin{array}{l}\text { Nitrogen } N \text { yang masuk kedalam ekosistem } \\
\text { perairan }\end{array}$ & 1.9 & Fitriani, 2017 \\
\hline$\beta$ & $\begin{array}{l}\text { Tingkat penurunan biomassa akibat sintesis } \\
\text { asam lemak }\end{array}$ & 0.5 & Fitriani, 2017 \\
\hline$\varepsilon_{1}$ & Proporsi asam lemak dari sintesis biomassa & 0.5 & Dibangkitkan \\
\hline
\end{tabular}




\begin{tabular}{|c|l|c|c|}
\hline$\varepsilon_{2}$ & Proporsi asam lemak dari sintesis biomassa & 0.8 & Dibangkitkan \\
\hline$\delta$ & Koefisien pelepasan karbon dioksida/respirasi & 2.6 & Nacong, 2014 \\
\hline$\gamma$ & Koefisien mobilisasi asam lemak & 3 & Nacong, 2014 \\
\hline
\end{tabular}

\subsubsection{Simulasi Tanpa Kendali}

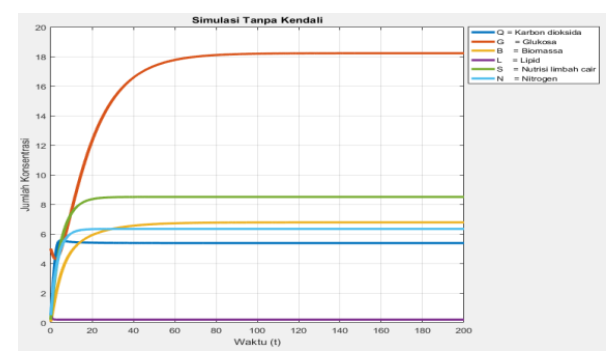

Gambar 2 : Kurva tanpa kendali intensitas cahaya dan nutrisi limbah cair

Gambar 2 memperlihatkan kuota karbon dioksada (Q) dengan nilai awal 0,5 mengalami peningkatan sebesar 5,569 ppm pada hari ke- 5 kemudian terus mengalami penurunan sampai pada hari ke- 80 yang merupakan titik setimbangnya. Glukosa (G) dengan nilai awal 5 mengalami penurunan konsentrasi sebesar 4,321 ppm pada hari ke- 3 kemudian mengalami peningkatan konsentrasi hingga mencapai 18,22 ppm pada hari ke- 125 yang merupakan titik setimbangnya. Nutrisi limbah cair (S) dengan nilai awal $0.2 \mathrm{~g} /$ liter mengalami peningkatan jumlah konsentrasi sebesar $8,348 \mathrm{~g} /$ liter pada hari ke- 20 kemudian mulai stabil pada hari ke- 48 dengan konsentarasi 8,499. Nitrogen $(\mathrm{N})$ dengan nilai awal $0,5 \mathrm{~g} /$ liter mengalami peningkatan konsentrasi 6,399 g/liter pada hari ke- 29 yang merupakan titik setimbangnya. Biomassa dengan nilai awal 0,06 mengalami peningkatan konsentrasi sebesar 5,915 g/liter pada hari ke- 20 diakibatkan oleh meningkatnya konsentrasi glukosa, nutrisi limbah cair, dan nitrogen, kemudian mulai stabil pada hari ke- 105. Lipid dengan nilai awal 0.6 mengalami penurunan konsentrasi sebesar $0.2 \mathrm{~g} /$ liter pada hari ke- 4 yang merupakan titik setimbangnya. Hal ini memberikan arti mikroalga hanya bertumbuh menghasilkan biomassa saja. Ketika pengaturan terhadap limbah cair, proses fotosintesis hanya memberikan input terhadap pertumbuhan biomassa saja. Lipid yang dihasilkan menurun seiring dengan pertambahan waktu dapat diartikan bahwa lipid yang dihasilkan hanya mampu untuk mempertahankan eksistensi mikroalga, tanpa bisa dimanfaatkan untuk diproduksi menjadi biodiesel.

\subsubsection{Simulasi Dengan Kendali}

Untuk sistem dengan kendali, kurva kuota karbon dioksida $(Q)$, glukosa $(G)$, biomassa mikroalga (B), kuota lipid (L), nutrisi limbah cair $(\mathrm{S})$, dan nutrisi nitrogen pupuk urea $(\mathrm{N})$ akan disimulasikan untuk empat keadaan, yaitu 
1. Kurva dengan kendali intensitas cahaya 2-9 klux dan nutrisi limbah cair tahu 0.01-0.07 g/liter

2. Kurva dengan kendali intensitas cahaya 2-9 klux dan nutrisi limbah cair tapioka $0.5 \mathrm{~g} / \mathrm{liter}$

3. Kurva dengan kendali intensitas cahaya 2-9 klux dan nutrisi limbah cair industri $0.95 \mathrm{~g} / \mathrm{liter}$

4. Kurva dengan kendali intensitas cahaya 2-9 klux dan nutrisi limbah cair rumah tangga $0.9 \mathrm{~g} / \mathrm{liter}$

Pada setiap simulasi akan dilakukan komparasi terhadap kurva yang menyatakan keadaan sistem tanpa kendali.

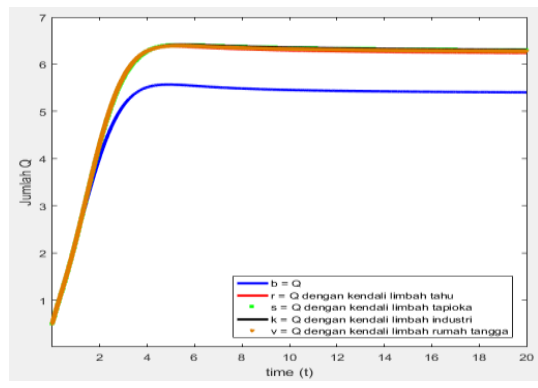

(a)

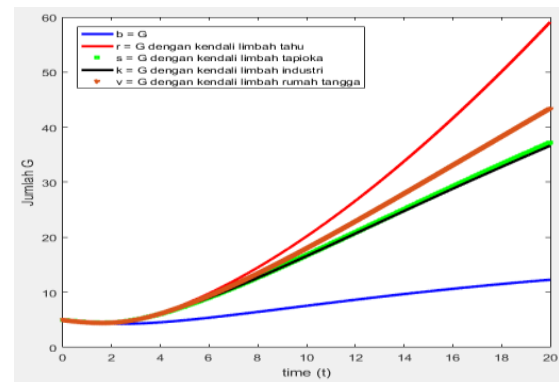

(b)

Gambar 3 : Kurva Perubahan Konsentrasi Kuota Karbon Dioksida (a) dan Kurva Perubahan Konsentrasi Glukosa (b)

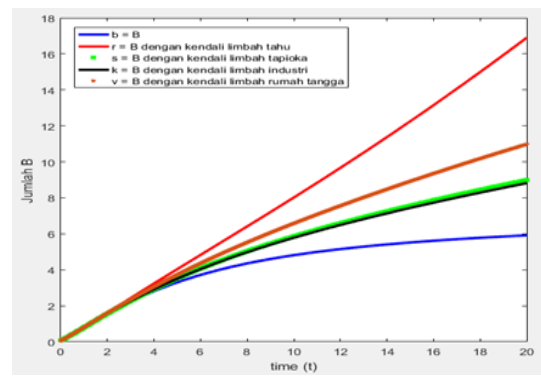

(a)

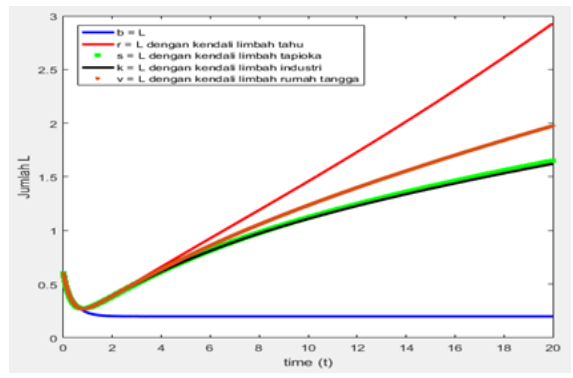

(b)

Gambar 4 : Kurva Perubahan Konsentrasi Biomassa (a) dan Kurva Perubahan Konsentrasi Kuota Lipid (b) 


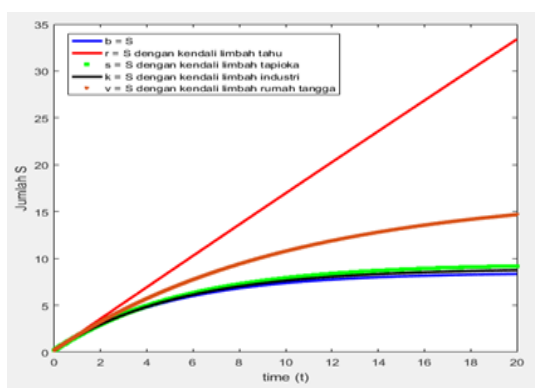

(a)

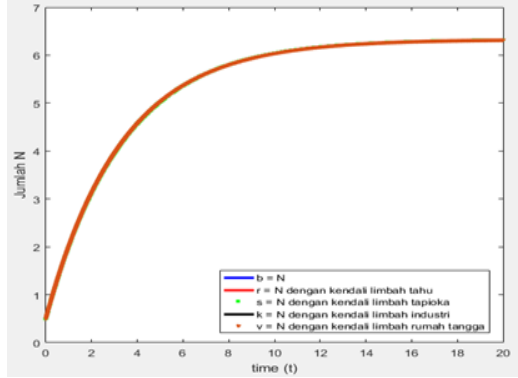

(b)

Gambar 5 : Kurva Perubahan Konsentrasi Kuota Lipid (a) dan Kurva Perubahan Konsentrasi Nitrogen (b)

\subsection{Pembahasan}

Gambar 3a memperlihatkan bahwa sebelum dilakukan pengontrolan, konsentrasi kuota karbon dioksida terus meningkat hingga mencapai 5,569 ppm pada hari ke- 5. Setelah dilakukan pengontrolan konsentrasi kuota karbon dioksida, peningkatan tertinggi dapat mencapai 6,41 ppm pada hari ke- 5 dengan pengaturan intensitas cahaya 2-9 klux dan limbah cair industri. Jenis nutrisi limbah cair tahu, tapioka, dan rumah tangga memberikan konsentrasi kuota karbon lebih rendah dengan limbah cair tahu memberikan konsentrasi kuota karbon terendah yaitu sebesar 6,376 ppm. Hasil ini memperlihatkan bahwa keempat jenis nutrisi limbah memiliki kemampuan yang sama dalam meningkatkan ketersediaan kuota karbon dioksida. Gambar 3b memperlihatkan terjadinya akselerasi perubahan glukosa yang lambat jika tanpa kendali. Limbah tapioka dan industri memiliki kemampuan yang sama terhadap peningkatan akselerasi pembentukan glukosa. Limbah tahu memberikan peningkatan akselerasi yang lebih tinggi lagi dari limbah tapioka dan industri, namun yang paling tinggi dalam memberikan kontribusi dalam peningkatan kuota karbon adalah limbah rumah tangga. Gambar 4 memperlihatkan terjadinya akselerasi perubahan glukosa yang lambat jika tanpa kendali. Limbah tapioka dan industri memiliki kemampuan yang sama terhadap peningkatan akselerasi pembentukan glukosa. Limbah tahu memberikan peningkatan akselerasi yang lebih tinggi lagi dari limbah tapioka dan industri, namun yang paling tinggi dalam memberikan kontribusi dalam peningkatan kuota karbon adalah limbah rumah tangga.

Gambar 4a memperlihatkan terjadinya akselerasi perubahan biomassa yang lambat jika tanpa kendali. Limbah tapioka dan industri memiliki kemampuan yang sama terhadap peningkatan akselerasi pembentukan biomassa. Limbah tahu memberikan peningkatan akselerasi yang lebih tinggi lagi dari limbah tapioka dan industri, namun yang paling tinggi dalam memberikan kontribusi dalam peningkatan kuota karbon adalah limbah rumah tangga. 
Gambar 4b memperlihatkan terjadinya akselerasi perubahan lipid yang lambat jika tanpa kendali. Limbah tapioka dan industri memiliki kemampuan yang sama terhadap peningkatan akselerasi pembentukan lipid. Limbah tahu memberikan peningkatan akselerasi yang lebih tinggi lagi dari limbah tapioka dan industri, namun yang paling tinggi dalam memberikan kontribusi dalam peningkatan kuota karbon adalah limbah rumah tangga.

Gambar 5a memperlihatkan terjadinya akselerasi perubahan nutrisi limbah cair yang lambat jika tanpa kendali. Limbah tapioka dan industri memiliki kemampuan yang sama terhadap peningkatan akselerasi pembentukan nutrisi limbah cair. Limbah tahu memberikan peningkatan akselerasi yang lebih tinggi lagi dari limbah tapioka dan industri, namun yang paling tinggi dalam memberikan kontribusi dalam peningkatan kuota karbon adalah limbah rumah tangga. Gambar 5b memperlihatkan semua jenis limbah cair tidak memberikan kontribusi dalam peningkatan ketersediaan nitrogen dalam model pertumbuhan mikroalga

\section{KESIMPULAN}

Dari hasil penelitian yang telah dilakukan, maka kesimpulan yang dapat ditarik yaitu sebagai berikut:

1. Bentuk model kendali optimal intensitas cahaya dan nutrisi limbah cair pada mikroalga adalah sebagai berikut:

$$
\begin{aligned}
& \frac{d Q}{d t}=\delta B+\gamma L-\alpha_{1} Q B \\
& \frac{d G}{d t}=u_{1} \alpha_{2} Q B-\mu G \\
& \frac{d B}{d t}=\mu G+\rho_{1} S+\rho_{2} N-\beta B \\
& \frac{d L}{d t}=\varepsilon_{1}+\varepsilon_{2} B-\gamma L \\
& \frac{d S}{d t}=\theta_{1}-u_{2} \rho_{1} S \\
& \frac{d N}{d t}=\theta_{2}-\rho_{2} N
\end{aligned}
$$

2. Diperoleh titik kritis dari model kendali optimal intensitas cahaya dan nutrisi limbah cair pada mikroalga, yaitu :

$T=\left\{Q=\frac{u_{2} \varepsilon_{1} \beta+\delta \theta_{1}+\delta u_{2} \theta_{2}+\varepsilon_{2} \theta_{1}+\varepsilon_{2} u_{2} \theta_{2}}{\alpha_{1}\left(\alpha_{1}\left(\theta_{1}+u_{2} \theta_{2}\right)+u_{1} u_{2} \alpha_{2} \varepsilon_{1}\right)}, G=-\frac{u_{1} \alpha_{2}\left(\varepsilon_{1} \beta u_{2}+\delta \theta_{1}+\delta u_{2} \theta_{2}+\varepsilon_{2} \theta_{1}+\varepsilon_{2} u_{2} \theta_{2}\right)}{\mu u_{2}\left(-\beta \alpha_{1}+u_{1} \alpha_{2}\left(\delta+\varepsilon_{2}\right)\right)}, B=\right.$ $\left.-\frac{\alpha_{1}\left(\theta_{1}+u_{2} \theta_{2}\right)+u_{1} u_{2} \alpha_{2} \varepsilon_{1}}{u_{2}\left(u_{1} \alpha_{2}\left(\delta+\varepsilon_{2}\right)-\beta \alpha_{1}\right)}, L=\frac{\varepsilon_{1} u_{2}\left(-u_{1} \alpha_{2} \delta+\beta \alpha_{1}\right)+\varepsilon_{2} \alpha_{1}\left(\theta_{1}+u_{2} \theta_{2}\right)}{\gamma u_{2}\left(\beta \alpha_{1}-u_{1} \alpha_{2}\left(\delta+\varepsilon_{2}\right)\right)}, S=\frac{\theta_{1}}{u_{2} \rho_{1}}, N=\frac{\theta_{2}}{\rho_{2}}\right\} \quad$ Hasil $\quad$ analisa kestabilan menunjukkan bahwa sistem stabil dengan syarat stabil yaitu $\frac{\alpha_{1}}{\alpha_{2}}>\frac{\left(\delta+\varepsilon_{2}\right) u_{1}}{\beta}$.

3. Dari hasil penelitian diperoleh desain kendali optimal dengan Indeks Performance $J\left[u_{1}+\right.$ $\left.u_{2}\right]=\int_{t 0}^{t f} G(t)-S(t)-\frac{1}{2} u_{1}(t)^{2}-\frac{1}{2} u_{2}(t)^{2} d t \quad$ dan kondisi satasioner $u_{1}^{*}=\gamma_{2} \alpha_{2} Q B$ untuk kendali intensitas cahaya dan $u_{2}^{*}=-\gamma_{5} \rho_{1} S$ untuk kendali nutrisi limbah cair tahu, tapioka, industri, dan rumah tangga. Simulasi menunjukan biomassa dan lipid tertinggi terjadi pada pengaturan intensitas cahaya 2-9 klux dan nutrisi limbah limbah cair tahu. 


\section{DAFTAR PUSTAKA}

[1] Badan Pusat Statistik, Penduduk Indonesia menurut Provinsi 1971, 1980, 1990, 1995, 2000, dan 2010, 2012, (https://bps.go.id/LinkTabelStatis/view/id/1267, diakses : 09-10-2017)

[2] Chisti, Y, Biodiesel from Microalgae, Biotechnology Advances, 25, 2007, 294-306.

[3] Fitriani, Membangun model pertumbuhan biomassa mikroalga dengan dua sumber nutrisi eksternal, Skripsi, Fakultas Matematika dan Ilmu Pengetahuan Alam, Universitas Tadulako, 2017, Palu.

[4] Hajar, Kendali Karbondioksida Pada Model Pertumbuhan Alga, Thesis, Fakultas Matematika dan IImu Pengetahuan Alam, Institut Sepuluh Nopember, 2014, Surabaya.

[5] Nacong, N, Kendali Optimal Model Produksi Lipid Netral Pada Pertumbuhan Mikroalga dengan Keterbatasan Nutrisi, Thesis, Fakultas Matematika dan IImu Pengetahuan Alam, Institut Sepuluh Nopember, 2014, Surabaya.

[6] Ratianingsih, R., Azim, Nacong, N., Resnawati, Mardlijah and Widodo, B, Optimal Control of Nutrition Restricted Dynamics Model of Microalgae Biomass Growth Model, Journal of Phisics, 2017, Conference series. 